\title{
FISH STOCKING DENSITY INDUCED GROWTH RESPONSES OF SOME BIOGEOCHEMICAL CYCLING BACTERIAL POPULATION
}

\author{
BHAKTA, J.N. ${ }^{2}$; BISWAS, J. K.. ; BHAKTA, P. ${ }^{\text {; }}$ MUNEKAGE, Y. ${ }^{2}$ \& JANA, B.B. ${ }^{1}$ \\ 'Department of Zoology, University of Kalyani, Kalyani-741 235, West Bengal, India, \\ Isnjbhakta@rediffmail.com \\ ${ }^{2}$ Department of Environmental Engineering, Faculty of Agriculture, Kochi University, B200, Monobe, \\ Nankoku, Kochi - 783-8502, Japan
}

\begin{abstract}
Bhakta, J.N.; Biswas, J.K.; Bhakta, P.; Munekage, Y. \& Jana, B.B. 2009. Fish stocking density induced growth responses of some biogeochemical cycling bacterial population. Braz. J. Aquat. Sci. Technol. 13(2):45-50. ISSN 1808-7035. Experiment was performed to ascertain the effect of fish stocking density on population growth performance of some biogeochemical cycling bacteria in carp culture system. Advanced fry of Catla catla L., Labeo bata Ham. and Cyprinus carpio L. were introduced into tanks @ 8,13, 16 and 32 fry tank $^{-1}$ maintaining the ratio of $C$. catla -2 : L. bata -3 : C. carpio -3. Each tank was fertilized with mixed fertilizer @ $200 \mathrm{~g} \mathrm{week}^{-1}$ during the rearing period of 150 days. Water samples were collected for examination of bacterial population, primary productivity and water quality parameters at weekly and biweekly intervals. Growth of fish was recorded at regular intervals. Statistical analysis of collected data was done by ANOVA and LSD for separation of mean $(P<0.05)$. Bacterial growth rate and productivity tended to rise with increasing stocking density showing maximum at stocking density 32 fry tank $^{-1}$ whereas, fish growth exhibited an increasing trend upto stocking density 16 fry tank $^{-1}$ and declined in further increment of fish density. Stocking density dependent growth efficiency of different bacteria (heterotrophic bacteria, cellulose decomposing bacteria, denitrifying bacteria and phosphate solubilizing bacteria) varied from 18 to $62.7 \%, 45$ to $140 \%, 61$ to $238 \%$ and 79 to $382 \%$ in stocking density 8, 13, 16 and 32 fry tank $^{-1}$, respectively. Results clearly revealed that higher stocking density of fishes liberates higher quantity of faecal matter containing proportionately greater amount of nutrients having more scope for bacteria to act upon the faecal matter resulting in higher bacterial population and productivity in one hand and fish growth inhibition due to stressful and uncongenial environmental condition developed by means of heavy nutrient load on the other hand. Therefore, it may be concluded that stocking density influencing the growth of biogeochemical cycling bacterial population in fish culture system.
\end{abstract}

Keywords: Carp fry, Stocking density, Bacterial population, Bacterial growth efficiency, Productivity

\section{INTRODUCTION}

Bacteria are most abundant and important biological component involved in the transformation and mineralization of organic matter in the biosphere (Cho \& Azam, 1988; Pomeroy et al., 1991; Williams, 1981). Specially, the biogeochemical cycling bacteria play a key role in the nutrient dynamics of fish farming ponds. They are also basic contributors to the evolution of the chemical quality of aquatic systems controlling the dynamic of biogeochemical cycles and the so called self purification processes. For good understanding of the role of bacteria in these changes, it is required that many parameters be taken into account (Bianchi, 1998), for example, accurate measurement of bacterial densities and of their physiological state, metabolic activities and regulation factors. Heterotrophic bacteria contribute to the cycles of nutrients in two major ways: by the production of new bacterial biomass (secondary production) and by the remineralization of nutrients (Giorgio \& Cole, 1998). Understanding this dual character of bacteria in aquatic ecosystems is a central paradigm of contemporary microbial ecology (Billen, 1984; Ducklow \& Carlson, 1992; Pomeroy et al., 1991).

Bacterial growth efficiency is the quantity of bacterial biomass synthesized per unit of substrate assimilated. In the process of growth, various compounds, elements and minerals are converted into cell material at the expense of the energy source. Organic substrate is an important factor which is taken up by a bacterial cell will be partly used in catabolic reactions to generate ATP and partly used in anabolic reactions for biomass synthesis (Dawes, 1985). In the absence of exogenous substrates, minimum maintenance energy requirements must be supported by degradation of biomass through endogenous metabolism.

Various intrinsic and extrinsic factors affect the favourable environment for bacterial population growth as well as fish growth in the aquaculture ponds. According to Bhakta (2003) and Bhakta et al. (2006), biogeochemical cycling bacteria population is influenced to great extend by fertilizer dose. Parallel with fertilizers, the fish stocking density also another important factor 
in regulating bacterial population for sustainable fish farming. Lack of information regarding the stocking density dependent response of bacterial population is a main driving force of the present concern. This study has been attempted to ascertain the effect of fish stocking density on bacterial population growth and its ecological bases in the regulation of bacterial growth efficiency.

\section{MATERIAL AND METHODS}

Study was conducted in fifteen cement tanks (4500 I; $\left.3 \times 1.5 \times 1 \mathrm{~m}^{3}\right)$ using different stocking densities, provided with dry soil and filled with ground water $(\mathrm{pH}$ 7.4) a week prior to experiment. Each tank was fertilized with mixed fertilizer @ $200 \mathrm{~g} \mathrm{tank}^{-1}$ week $^{-1}$ (equivalent to $23,000 \mathrm{~kg} \mathrm{ha}^{-1} \mathrm{year}^{-1}$ ) prepared by mixing of poultry droppings (PD), cattle manure (CM), single super phosphate (SSP) and urea (U), which was determined to be optimum for pond fertilization (Jana et al., 2001).

Advanced fry of catla (Catla catla L., $1.2 \pm 0.05$ g), bata (Labeo bata Ham., $1.8 \pm 0.23 \mathrm{~g}$ ) and common carp (Cyprinus carpio L., $2.15 \pm 0.2 \mathrm{~g}$ ) were procured from a local farm and acclimatized for a week. After one week of initial fertilization, fish fry was introduced into tanks following the stocking densities $8,13,16$, and 32 fry tank ${ }^{-1}$ (herein called $\mathrm{SD}_{8}, \mathrm{SD}_{13}, \mathrm{SD}_{16}$ and $\mathrm{SD}_{32}$ ), which were equivalent to $17775,28880,35550$ and 71100 fry ha $^{-1}$ maintaining the ratio catla- 2 : bata- 3 : common carp3. A set without introduction of fish was used as control (C). Each stocking density of fish and control had three replicates. The fishes were reared for 150 days. Naturally produced plankton was the source of food for the fishes as no supplementary feeding was provided during the culture period.

Water samples were collected from different sites of each tank, pooled into one and used aseptically for microbial examination at a fixed hour of the day $(10.00$ h) at weekly intervals during the early phase and biweekly thereafter. Aliquots of ten-fold dilution $10^{-1}$ to $10^{-4}$ of collected water were made in sterile distilled water. Conventional spread plate technique under aerobic conditions was used to enumerate viable counts of aerobic heterotrophic bacteria (HB), cellulose decomposing bacteria (CDB), denitrifying bacteria (DNB) and phosphate solubilizing bacteria (PSB) following the methods described by Rodina (1972) and Austin (1990) at an incubation temperature of $35^{\circ} \mathrm{C}$ for three days. Each dilution of the sample was plated in triplicate and arithmetical means of the three petri plates was used in the present study. Water quality parameters were examined following the standard methods described by APHA (1995). Primary productivity of the phytoplankton was determined using the light and dark bottle method described by Vollenweider (1974). Increments of fish growth and their survival were recorded at the time of harvest.

Bacterial growth efficiency (BGE) for heterotrophic bacteria $(\mathrm{HB})$ of different stocking density over control was calculated using the formula as follows:

$$
B G E(\%)=\frac{H B_{T}-H B_{c}}{H B_{C}} \times 100
$$

where,

$\mathrm{HB}_{\mathrm{T}}=$ Mean bacterial number in water of the treatments $\mathrm{HB}_{\mathrm{C}}=$ Mean bacterial number in water of the control

All data were expressed as mean \pm S.E. and statistically analyzed by one way ANOVA (Gomez \& Gomez, 1984). Prior analysis, the assumptions of normal distributions and homogeneity of the variance were checked using Kolmogrov-Smirnov and Cochran's tests, respectively. If the main effect was found significant, the ANOVA was followed by a LSD (least significance difference) test. All statistical tests were considered significant at $5 \%$ probability level using statistical package EASE and M-STAT.

\section{RESULTS}

\section{Bacterial population}

Four bacterial populations (HB, CDB, PSB and DNB) showed significant fish density dependent responses (ANOVA, $\mathrm{P}<0.05)$. The number of $\mathrm{HB}(50-$ $\left.308 \times 10^{4} \mathrm{cfu} \mathrm{ml}^{-1}\right), \mathrm{CDB}\left(46-233 \times 10^{2} \mathrm{cfu} \mathrm{ml}^{-1}\right)$, PSB $\left(22-314 \times 10^{1} \mathrm{cfu} \mathrm{ml}^{-1}\right)$ and DNB $\left(40-203 \times 10^{1} \mathrm{cfu} \mathrm{ml}^{-}\right.$ $\left.{ }^{1}\right)$ increased with increasing stocking densities of fish introduced and showing the following order of variations: $\mathrm{C}>\mathrm{SD}_{8}>\mathrm{SD}_{13}>\mathrm{SD}_{16}>\mathrm{SD}_{32}$. The mean counts observed in the highest stocking density $\left(\mathrm{SD}_{32}\right)$ were 15 to $79 \%$ in $\mathrm{HB}, 11$ to $53 \%$ in CDB, 42 to $195 \%$ in DNB and 26 to $142 \%$ in PSB higher than that occurred in remaining stocking densities $\left(\mathrm{SD}_{8}, \mathrm{SD}_{13}\right.$ and $\left.\mathrm{SD}_{16}\right)$. The counts of various group of bacterial population showed gradual rising response with period in different stocking density (Fig. 1).

Growth efficiency of bacteria (GEB) raged from $46-183 \%$ in $\mathrm{HB}, 18-79 \%$ in CDB, $62.7-382 \%$ in DNB and $41-242 \%$ in PSB in different stocking density.

\section{Water quality parameters}

Temperature and $\mathrm{pH}$ of water ranged from 26.6 to $32^{\circ} \mathrm{C}$ and $7.2-8.8$ during the period of experimentation, respectively. The concentrations of free carbon dioxide (1.3 to $7.1 \mathrm{mg} \mathrm{l}^{-1}$ ) and dissolved oxygen (7.6 to 17.89 $\mathrm{mg} \mathrm{l}^{-1}$ ) showed significant differences in different stocking density employed (Table 1). 
(A)

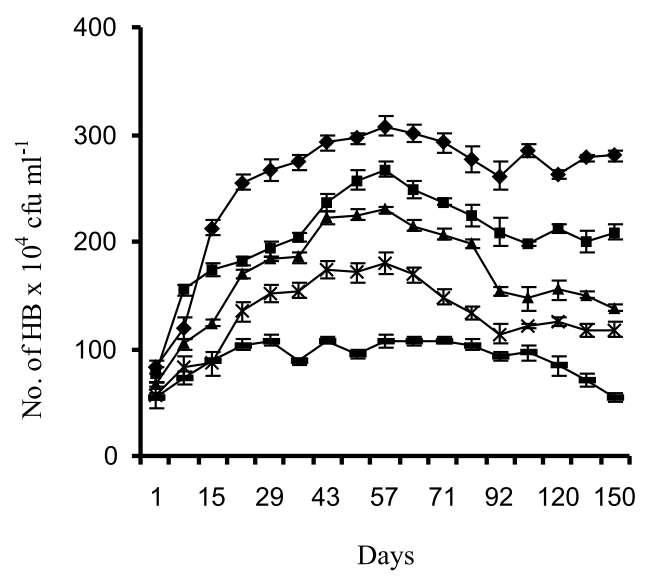

(C)

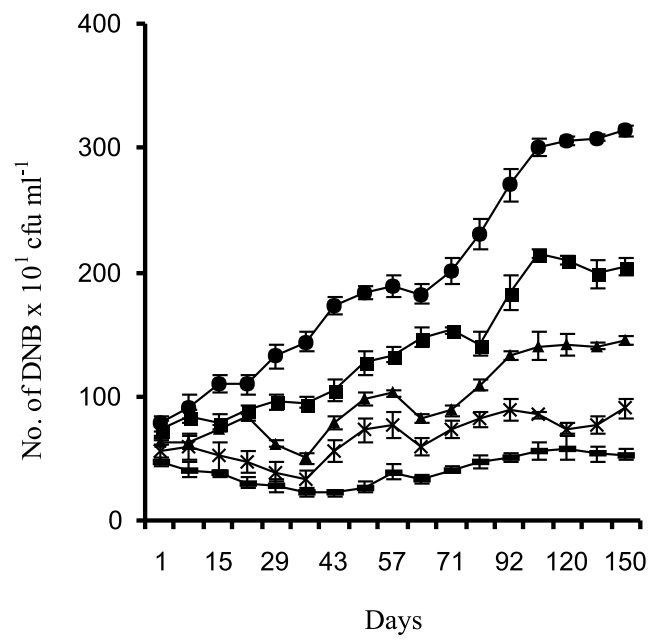

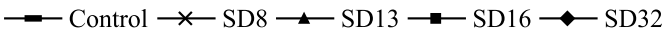

(B)

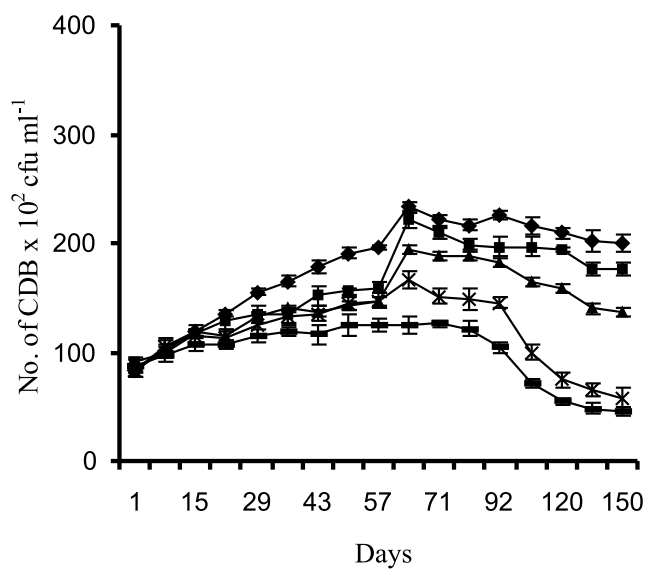

(D)

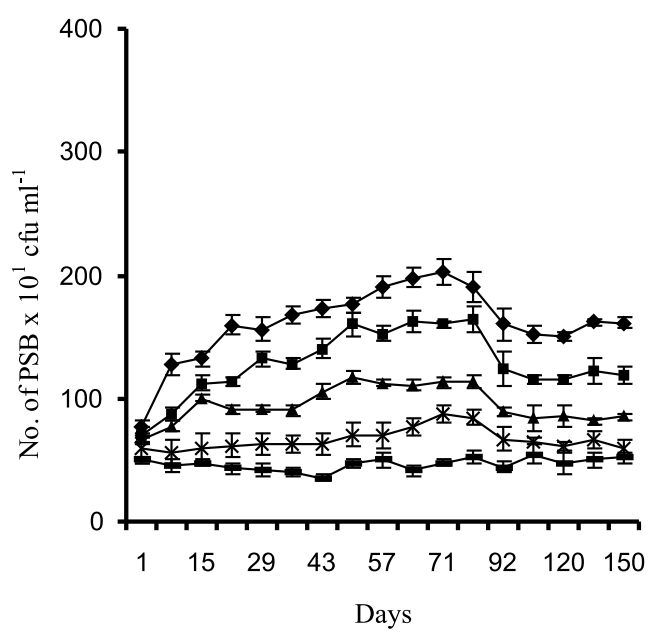

Figure 1 - Temporal response of HB (A), CDB (B), DNB (C) and PSB (D) in water of out door tanks stocked with different densities of carps.

Three nitrogen parameters (Ammonium- $\mathrm{N}$, Nitrite$\mathrm{N}$ and Nitrate- $\mathrm{N}$ ) showed density dependent significant differences (ANOVA, $P<0.05$ ). The concentrations varied from 0.085 to $0.366 \mathrm{mg} \mathrm{l}^{-1}$ in ammonium- $\mathrm{N}, 0.037$ to $0.211 \mathrm{mg} \mathrm{l}^{-1}$ in nitrite- $\mathrm{N}$ and $0.038-0.174 \mathrm{mg} \mathrm{l}^{-1}$ in nitrate$\mathrm{N}$ and increased with increasing stocking density. The orthophosphate concentration also exhibited a density dependent function and ranging from 0.095 to $0.313 \mathrm{mg}$ $\mathrm{I}^{-1}$ among all the stocking density employed (Table 1). Temporal responses of all nutrient parameters were gradual increasing trend in different stocking densities of fish (Table 1).

\section{Primary productivity of water}

The gross primary productivity $\left(53-397 \mathrm{mg} \mathrm{C} \mathrm{m}^{-}\right.$ $\left.{ }^{3} \mathrm{~h}^{-1}\right)$ and net primary productivity $\left(25.5-194 \mathrm{mg} \mathrm{C} \mathrm{m}^{-3} \mathrm{~h}\right.$ $\left.{ }^{1}\right)$ exhibited significant differences (ANOVA, $P<0.05$ ) among all stocking density and increased with increasing stocking density. The GPP and NPP also exhibit a rising response with time.

Growth, survival and yield of fish

Average weight of three fish species ranged from 7.2 to $43.5 \mathrm{~g}$ in catla, 8.4 to $50.25 \mathrm{~g}$ in bata and 10.5 to $75 \mathrm{~g}$ in common carp (Table 1). Survival of fish varied 
Table 1 - Mean values $( \pm$ S.E.) of water quality, primary productivity, fish growth and fish yield in different stocking densities of carps employed in out door tank. Same script among treatments (rows) revealed lack of significant difference.

\begin{tabular}{|c|c|c|c|c|c|}
\hline \multirow{2}{*}{ Criteria } & \multicolumn{5}{|c|}{ Stocking densities } \\
\hline & Control & $\mathrm{SD}_{8}$ & $\mathrm{SD}_{13}$ & $S_{D_{16}}$ & $\mathrm{SD}_{32}$ \\
\hline Temperature $\left({ }^{\circ} \mathrm{C}\right)$ & $28.5 \pm 1.5$ & $27.5 \pm 2.5$ & $29.8 \pm 1.3$ & $28.1 \pm 2.1$ & $29 \pm 1.5$ \\
\hline $\mathrm{PH}$ & 8.2 & 8.0 & 7.85 & 7.9 & 7.81 \\
\hline Free- $-\mathrm{CO}_{2}\left(\mathrm{mg} \mathrm{l}^{-1}\right)$ & $3.06 \pm 0.023^{\mathrm{D}}$ & $10.28 \pm 0.42^{C D}$ & $3.47 \pm 0.011^{\mathrm{C}}$ & $4.59 \pm 0.051^{B}$ & $5.51 \pm 0.034^{\mathrm{A}}$ \\
\hline $\mathrm{DO}\left(\mathrm{mg} \cdot \mathrm{L}^{-1}\right)$ & $9.61 \pm 0.08^{\mathrm{C}}$ & $11.38 \pm 0.05^{\mathrm{B}}$ & $11.56 \pm 0.17^{\mathrm{B}}$ & $12.22 \pm 0.011^{\mathrm{A}}$ & $12.58 \pm 0.28^{\mathrm{A}}$ \\
\hline $\mathrm{NH}_{4}-\mathrm{N}\left(\mathrm{mg} \mathrm{l}^{-1}\right)$ & $0.178 \pm 0.005^{\mathrm{E}}$ & $0.263 \pm 0.004^{\mathrm{D}}$ & $0.294 \pm 0.002^{C}$ & $0.32 \pm 0.005^{\mathrm{B}}$ & $0.366 \pm 0.009^{A}$ \\
\hline $\mathrm{NO}_{2}-\mathrm{N}\left(\mathrm{mg} \mathrm{l}^{-1}\right)$ & $0.078 \pm 0.001^{\mathrm{E}}$ & $0.11 \pm 0.005^{\mathrm{D}}$ & $0.134 \pm 0.002^{C}$ & $0.149 \pm 0.003^{B}$ & $0.164 \pm 0.001^{\mathrm{A}}$ \\
\hline $\mathrm{NO}_{3}-\mathrm{N}\left(\mathrm{mg} \mathrm{l}^{-1}\right)$ & $0.069 \pm 0.005^{\mathrm{D}}$ & $0.089 \pm 0.002^{C}$ & $0.106 \pm 0.002^{B}$ & $0.118 \pm 0.003^{A B}$ & $0.13 \pm 0.002^{A}$ \\
\hline $\mathrm{PO}_{4}-\mathrm{P}\left(\mathrm{mg} \mathrm{l}^{-1}\right)$ & $0.147 \pm 0.005^{\mathrm{D}}$ & $0.176 \pm 0.003^{C}$ & $0.183 \pm 0.004^{C}$ & $0.195 \pm 0.003^{B}$ & $0.218 \pm 0.006^{\mathrm{A}}$ \\
\hline $\begin{array}{ll}\text { Gross } & \text { primary } \\
\text { productivity } & \\
\left(\mathrm{mg} \mathrm{C}^{-3} \mathrm{~h}^{-1}\right) & \end{array}$ & $53 \pm 46^{\mathrm{D}}$ & $191 \pm 12^{C}$ & $211 \pm 5.2^{B C}$ & $238 \pm 7.51^{\mathrm{B}}$ & $288 \pm 7.5^{\mathrm{A}}$ \\
\hline $\begin{array}{l}\text { Net primary productivity } \\
\left(\mathrm{mg} \mathrm{C} \mathrm{m}^{-3} \mathrm{~h}^{-1}\right)\end{array}$ & $25 \pm 2.9^{\mathrm{D}}$ & $78.4 \pm 4.3^{C}$ & $93.88 \pm 3.8^{\mathrm{BC}}$ & $104 \pm 6.3^{B}$ & $137.87 \pm 4.5^{\mathrm{A}}$ \\
\hline Final weight of fish $(\mathrm{g})$ & - & $48 \pm 4^{\mathrm{A}}$ & $31.76 \pm 3^{B}$ & $28 \pm 4.2^{\mathrm{B}}$ & $10.4 \pm 3.2^{C}$ \\
\hline Survival (\%) & - & 100 & 100 & 100 & 89 \\
\hline Fish yield $\left(\mathrm{g} \operatorname{tank}^{-1}\right)$ & - & $386 \pm 4^{B}$ & $413 \pm 3.8^{B}$ & $441 \pm 5^{A}$ & $296 \pm 6^{C}$ \\
\hline
\end{tabular}

between 85 and 100\% in different stocking density. Fish yield increased directly with increasing stocking density till $\mathrm{SD}_{16}$, further increase of stocking density resulted in $32.86 \%$ decline of fish yield. The maximum fish yield was $441.34 \mathrm{~g} /$ tank in $\mathrm{SD}_{16}$ followed by $\mathrm{SD}_{13}, \mathrm{SD}_{8}$ and $\mathrm{SD}_{32}$.

\section{DISCUSSION}

Results of the present study demonstrated that different groups of biogeochemical cycling bacterial population increased with increasing fish stocking density in carp culture ponds. The biogeochemical microbial activities are regulated by the environmental complex in farming ponds that are managed under different stocking combinations (Jana \& Patel, 1984, 1985, 1990; Jana \& Ray, 1985a, b, 1986; Jana \& De, $1990,1993)$. The rate of increase in bacterial population was maximum in DNB and followed by PSB, HB and $\mathrm{CDB}$, respectively. Such, direct fish density dependent increase in the growth of different groups of bacteria in the fish growing tanks was the result of density dependent increase in production of metabolic wastes acting as a source of nutrients containing substrate for bacterial growth. Rate of growth efficiency of different biogeochemical cycling bacterial populations (HB, CDB, DNB and PSB) were 18 to $62.7 \%, 45$ to $140 \%, 61$ to $238 \%$ and 79 to $382 \%$ in $\mathrm{SD}_{8}, \mathrm{SD}_{13}, \mathrm{SD}_{16}$ and $\mathrm{SD}_{32}$, respectively (Fig. 2). It pronounces that fishes of higher stocking density substantially contribute towards more nutrient enrichment than lower one through their role of ichthyoeutrophication for bacterial growth. Generally, the behaviour of bacterial growth efficiency influenced by amount of substrate exposed and consumed by bacteria (Monod, 1942) or energy (ATP) produced from the substrate (Bauchop \& Elsden, 1960).

Increase rate of different bacterial density for per gram of fish (HB $0.083-1.97 \times 10^{4} \mathrm{cfu} \mathrm{ml}^{-1}$, CDB 0.069 $-0.3 \times 10^{2} \mathrm{cfu} \mathrm{ml}^{-1}$, DNB $0.064-0.523 \times 10^{1} \mathrm{cfu} \mathrm{ml}^{-1}$ and PSB $0.049-0.385 \times 10^{1} \mathrm{cfu} \mathrm{ml}^{-1}$ ) exhibited a gradual rising responses with increasing stocking density implying that the system of higher fish stocking density having more potentiality for growing the bacterial population than that of the lower one.

Correlation studies revealed that the nutrients concentrations was positively correlated with the growth of heterotrophic bacteria in different stocking density which indicating microbial degradation of metabolic wastes (decomposition) greatly responsible for the release of nutrients which was the direct function of both fish stocking density and thereby metabolic wastes. It is well known that the decomposition of organic fertilizer is carried out by bacteria, fungi, actinomycetes (Persson et al., 1980; Gaur et al., 1995; Boyd, 1995) releases the essential nutrients that sustained the biological productivity of the pond. Relationship between denitrifying bacterial population and ammonium-N concentration revealed that the fish excreted faecal matters contains favourably enough substrates for denitrifying bacterial growth which resulting in high concentration ammonium nitrogen in water (Fig. 3). According to Diana \& Fast (1989) higher stocking density often results in higher ammonia concentrations. It has been clearly established that the phosphorus flow is mainly related to phytoplankton activity in the water column and decomposition on the pond bottom, while nitrogen flow is mainly linked to autotrophic 


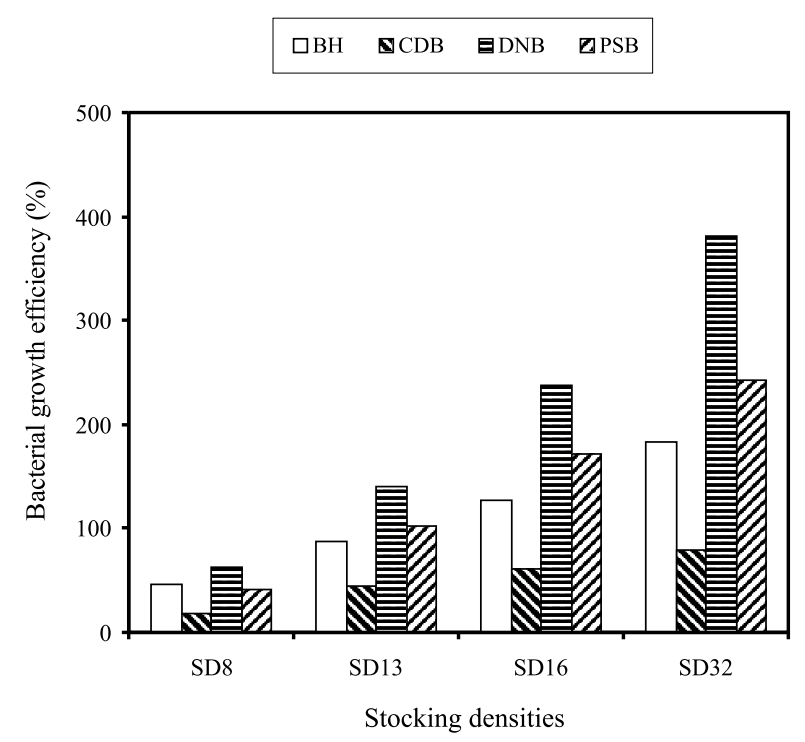

Figure 2 - Growth efficiency of heterotrophic bacteria, cellulose decomposing bacteria, denitrifying bacteria and phosphate solubilizing bacteria in water of out door tanks stocked with different densities of carps.

(photosynthesis) and heterotrophic (decomposition and nitrification) processes (Milstein et al., 2003).

\section{CONCLUSION}

As pond quality assessment parameters, productivity and fish yield are regulated by nutrients condition of the water released from microbial decomposition of organic and fish faecal matters that directly influencing the microbial population of the fish pond (Fig. 4). The present study also showed that productivity and fish yield were maximum at $\mathrm{SD}_{32}$ and $\mathrm{SD}_{16}$, respectively. From this point, it is obvious that fish yield is not always increased with increasing productivity of the ponds, because higher stocking density of fishes liberates higher quantity of faecal matter containing proportionately greater concentration of nutrients having more scope for bacteria to act upon the faecal matter resulting in higher bacterial population and productivity in one hand and fish growth inhibition due to stressful and uncongenial aquatic environment developed by means of heavy nutrients load on the other hand. Bhakta (2006) proposed that nutrient liberation criteria of faecal matters depend on the quantity of faecal matter, variation of fish species and fish size. Therefore, the above discussion affords us to draw a clear conclusion that growth of biogeochemical cycling bacterial population is largely governed by the stocking density of fish.

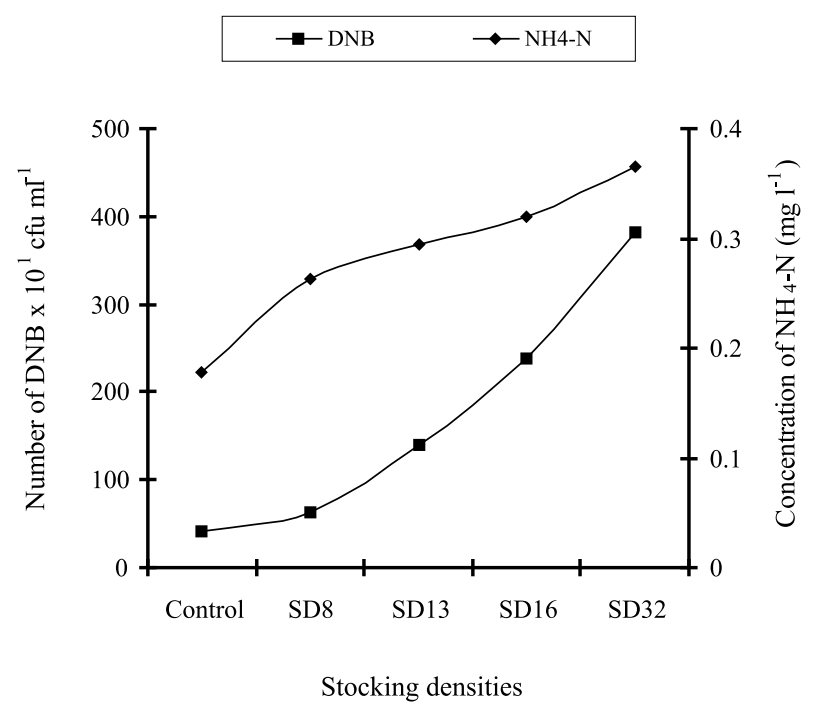

Figure 3 - Relationship between denitrifying bacterial population and concentration of ammonium- $\mathrm{N}$ in different stocking densities of carps.

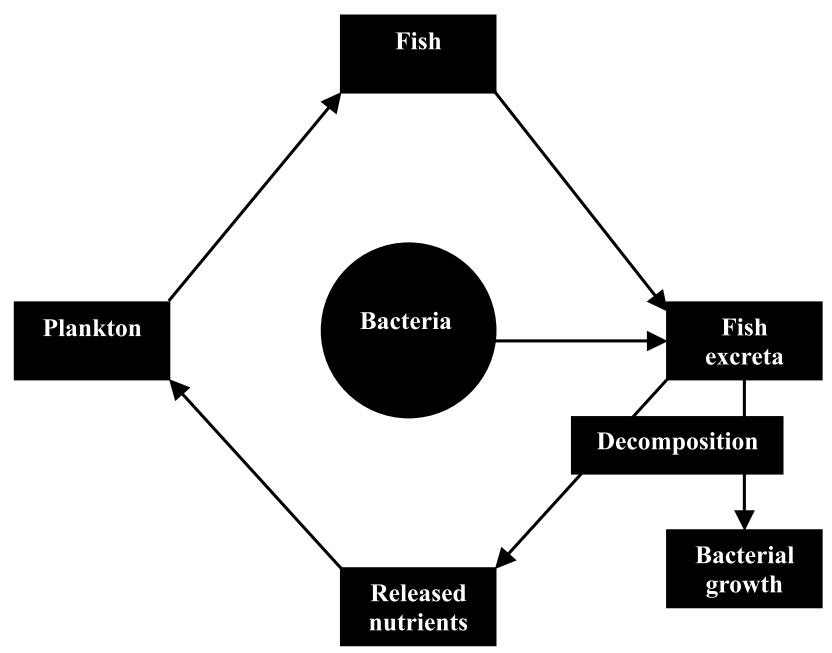

Figure 4 - Simplified pathway depicts decomposition and recycling of fish faecal matter and its influence on bacterial population growth.

\section{REFERENCES}

APHA 1995. Standard Methods for the Examination of Water and Wastewater. $19^{\text {th }}$ Edition. American Public Health Association, Washington, DC, 1038p.

Austin, B. 1990. Methods in Aquatic Bacteriology. John Wiley and Sons, New York, 425p.

Bauchop, T. \& Elsden, S.R. 1960. The growth of microorganisms in relation to their energy supply. J. Gen. Micro. 23:457-469.

Bhakta, J.N.; Bandyopadhyay, P.K. \& Jana, B.B. 2006. Effect of different doses of mixed fertilizer on some 
biogeochemical cycling bacterial population in carp culture pond. Tur. J. of Fish. and Aqu. Sc. 6:163169.

Bhakta, J.N. 2003. Fertilizer-microbial interactions in wastewater system: Influence of fertilizer dose and stocking density of fish. Ph. D. Thesis. University of Kalyani, Kalyani. 188p.

Bhakta, J.N. 2006. Nutrient value of excreta of some freshwater fish species. Env. and Ecol. 24S(2):370374.

Bianchi, M. 1998. Nouvelles approches d'étude des réseaux microbiens. Annuals Limnol. 34:465-473.

Billen, G. 1984. Heterotrophic utilization and regeneration of nitrogen. In: Hobbie, J.E. \& Williams, B.P. (eds.) Heterotrophic Activity in the Sea. Plenum, New York. 313-355 pp.

Boyd, C.E. 1995. Bottom Soils, Sediment, and Pond Aquaculture. Chapman and Hall, New York, 348p.

Cho, B.C. \& Azam, F. 1988. Major role of bacteria in biogeochemical fluxes in the ocean's interior. Nature 332:441-443.

Dawes, E.A. 1985. Starvation, survival and energy reserves. In: Fletcher, M. \& Foodgate, G.D. (eds.) Bacteria in Their Natural Environment. Academic, New York. 43-79 pp.

Diana, J.S. \& Fast, A.W. 1989. The effects of water exchange rate and density on yield of the walking catfish, Clarias fuscus. Aquaculture 78:267-276.

Ducklow, H.W. \& Carlson, C.A. 1992. Oceanic bacterial production. Adv. Microb. Ecol. 12:113-181.

Gaur, A.C.; Dargan, K.S. \& Neelakantan, K.S. 1995. Organic Manure. Publication and Information Division, Indian Council of Agricultural Research, New Delhi, India, 159p.

Giorgio, P.A.D. \& Cole, J.J. 1998. Bacterial growth efficiency in natural aquatic systems. Annual Rev. of Ecol. and Syst. 29:503-541.

Gomez, K.A. \& Gomez, A.A. 1984. Statistical Procedures for Agricultural Research $2^{\text {nd }}$ Edition. John Wiley and Sons, New York, 680p.

Jana, B.B.; Chakrabarti, P.; Biswas, J.K. \& Ganguly, S. 2001. Biogeochemical cycling bacteria as indices of pond fertilization: Importance of CNP ratios of input fertilizers. J. of Appl. Micro. 90:733-740.

Jana, B.B. \& De, U.K. 1990. Spatial and seasonal distribution of heterotrophic bacteria in pond water and sediments under different management practices. Int. Rev. der Ges. Hyd. 75:639-648.

Jana, B.B. \& De, U.K. 1993. Management induced variability of the bacterioplankton in fish farming ponds. J. of Aqu. in the Trop. 8:131-140.
Jana, B.B. \& Patel, G.N. 1984. Spatial and seasonal variations of phosphate solubilizing bacteria in fish ponds of varying fish farming managements. Arch. fur Hyd. 101:555-568.

Jana, B.B. \& Patel, G.N. 1985. Distribution pattern denitrifying bacteria in fish ponds of differing farming managements. Arch. fur Hyd. 103:291-303.

Jana, B.B. \& Patel, G.N. 1990. Pattern and magnitude of nitrate reduction in fish ponds differing in management practices. Aqua. Hung. 6:53-63.

Jana, B.B. \& Roy, S.K. 1985a. Distribution patterns of protein mineralizing and ammonifying bacterial populations in fish farming ponds under different management systems. Aquaculture 44:57-65.

Jana, B.B. \& Roy, S.K. 1985b. Spatial and temporal changes of nitrifying bacterial population in fish ponds of different management practices. J. of Appl. Bact. 59:195-204.

Jana, B.B. \& Roy, S.K. 1986. Seasonal and spatial distribution pattern of nitrogen fixing bacteria in fish ponds under different management systems. Hydrobiologia 137:45-54.

Milstein, A.; Azim, M.E.; Abdul, W.M. \& Verdegem, M.C.J. 2003. The Effects of periphyton, fish and fertilizer dose on biological processes affecting water quality in earthen fish ponds. Env. Biol. of Fish. 64:247-260.

Monod, J. 1942. Recherches sur la criossance des cultures bact'eriennes. Hermann and Co., Paris.

Persson, T.; Baath, E.; Clarholm, M.; Lundkvist, H.; Soderstrom, B. \& Sohlenius, B. 1980. Trophic structure, biomass dynamics and carbon metabolism of soil organisms in Scots pine forest. Ecol. Bull. 32:419-462.

Pomeroy, L.R.; Wiebe, W.J.; Deibel, D.; Thompson, R.J. \& Rowe, G.T. 1991. Bacterial responses to temperature and substrate concentration during the Newfoundland spring bloom. Mar. Ecol. Prog. Ser. 75:143-159.

Rodina, A.G. 1972. Methods in Aquatic Microbiology. In: Colwell, R.R. \& Zambruski, M.S. (eds.) University Park Press, Baltimore, Butterworths, London, 461p.

Vollenweider, R.A. 1974. A Manual on Methods for Measuring Primary Production in Aquatic Environments. Blackwell Scientific Publications, Oxford, 225p.

Williams, P.B. 1981. Microbial contribution to overall marine plankton metabolism: direct measurements of respiration. Oceanol. Acta 4:359-364.

Received: January 28, 2009 Accepted: November 13, 2009 